\title{
EVALUASI KEBIJAKAN PENANGANAN PECANDU NARKOTIKA OLEH BADAN NARKOTIKA NASIONAL PROVINSI JAWA BARAT
}

\author{
Diani Utami Nafisah ${ }^{1}$, Mohammad Benny Alexandri², R. Ira Irawati ${ }^{3}$ \\ Program Pasca Sarjana Kebijakan Publik \\ Fakultas Ilmu Sosial dan Ilmu Politik \\ Universitas Padjadjaran \\ nafisahdiani@gmail.com, mohammad.benny@unpad.ac.id², ira.irawati@unpad.ac.id³
}

\begin{abstract}
ABSTRAK
Penyalahgunaan Narkotika merupakan kejahatan yang sudah masuk ke dalam fase Bencana di Indonesia. Jawa Barat adalah salah satu wilayah dengan angka prevalensi penyalahgunaan Narkotika tertinggi dari 34 Provinsi pada tahun 2017 yaitu sebesar 645,482 jiwa dengan populasi sebanyak 35,242,100 jiwa. Tujuan dari penelitian ini yaitu untuk mengetahui bagaimana evaluasi yang dilakukan Badan Narkotika Nasional Jawa Barat dalam penanganan pecandu narkotika di Jawa Barat. Evaluasi adalah cara untuk menilai sejauh mana sebuah kebijakan dapat berjalan sesuai dengan tujuan yang ingin dicapai. Penelitian ini menggunakan metode kualitatif dengan pendekatan studi kepustakaan dan studi dokumentasi. Penulis menggunakan enam dimensi langkah-langkah evaluasi yang dikemukakan oleh Milstein untuk mengevaluasi penanganan pecandu narkotika oleh Badan Narkotika Nasional Provinsi Jawa Barat. Langkah-langkah evaluasi tersebut yaitu Engage stakeholder, Describe the program, Focus the Evaluation Design, Gather Credible Evidence, Justify Conlusions, Ensure Use and Share Lessons Learned.
\end{abstract}

Kata kunci: Evaluasi, Pecandu Narkotika, Jawa Barat

\begin{abstract}
Narcotics abuse is a crime that has entered into the Disaster phase in Indonesia. West Java is one of the regions with the highest prevalence of Narcotics abuse from 34 provinces in 2017, which amounted to 645,482 people with a population of 35,242,100 people. The purpose of this study was to find out how the evaluation was carried out by the West Java National Narcotics Agency in handling narcotics addicts in West Java. Evaluation is a way to assess the extent to which a policy can run in accordance with the objectives to be achieved. This study uses a qualitative method with a library study approach and documentation study. The author uses six dimensions of evaluation steps proposed by Milstein to evaluate the handling of narcotics addicts by the National Narcotics Agency of West Java Province. The evaluation steps are Engage stakeholders, Describe the program, Focus the Evaluation Design, Gather Credible Evidence, Justify Conlusions, Ensure Use and Share Lessons Learned.
\end{abstract}

Keywords: Evaluation, Narcotics addicts, West Jawa

\section{PENDAHULUAN}

Penyalahgunaan narkotika merupakan permasalahan besar yang terjadi dalam lingkup nasional dan internasional. Permasalahan ini tidak habishabisnya dibicarakan, sehingga pemerintah terus berjuang dan berusaha keras untuk memberantas penyalahgunaan narkotika di Indonesia karena ini adalah ancaman yang serius dalam kehidupan berbangsa dan bernegara. Seperti, memberikan dampak yang berbahaya terhadap aspek kesehatan, sosial budaya, politik, ekonomi serta pertahanan dan keamanan. Penyalahgunaan narkotika biasanya dimulai dengan rasa ingin tahu untuk sekedar coba-coba mengikuti teman, untuk mengurangi rasa nyeri, kelelahan ketegangan jiwa atau sebagai hiburan dan pergaulan. Tetapi, jika taraf sekedar coba-coba kemudian dilakukan secara berkelanjutan dan terus menerus akan berubah dan masuk ke dalam taraf ketergantungan. Ketergantungan terhadap narkoba dapat menimbulkan gangguan kesehatan jasmani dan rohani yang lebih jauh dapat menyebabkan penderitaan dan kesengsaraan sampai pada kematian sia-sia (M.sianipar, 2004). Penyalahgunaan narkoba bukan lagi merupakan kejahatn tanpa korban (victimless crime) tetapi penyalahgunaan ini sudah termasuk kedalam kejahatan 


\section{Evaluasi Kebijakan Penanganan Pecandu Narkotika Oleh Badan Narkotika Nasional Provinsi Jawa Barat (Diani Utami Nafisah, Mohammad Benny Alexandri, R. Ira Irawati)}

yang memakan jutaan korban dan bencana yang berkepanjangan bagi seluruh rakyat. Bahkan dampak dari penyalahgunaan narkotika ini sudah dikategorikan sebagai bencana yang sangat besar seperti yang dikemukakan oleh Ketua Umum Gerakan Nasional Anti-Narkotika (Granat), Henry Yosodiningrat yang menyatakan, “ Seperti sering saya katakan, kondisi Indonesia sekarang sudah dalam bencana narkoba. Bukan lagi sekedar darurat, tapi dalam bencana narkoba” (dalam Muhaimin, 2012). Menurut Pasal 1 angka 1 Undang-undang No. 35 Tahun 2009 tentang Narkotika, Narkotika adalah zat atau obat yang berasal dari tanaman atau bukan tanaman, baik sintetis maupun semisintetis yang dapat menyebabkan penurunan atau perubahan kesadaran, hilangnya rasa, mengurangi sampai menghilangkan rasa nyeri dan dapat menimbulkan ketergantungan yang dibedakan ke dalam golongan-golongan sebagaimana terlampir dalam undang-undang ini.

Berdasarkan pernyataan United Nations Office Drug and Crime (UNODC) yang menyebutkan bahwa pada tahun 2014 hampir seperempat miliar orang pada rentang usia 15-64 tahun diperkirakan menggunakan narkoba, yaitu sekitar 246 juta orang atau 5,2\% dari populasi dunia sekitar 6 miliar orang. Dari berbagai macam jenis penyalahgunaan narkoba, penyalahgunaan pemakaian ganja merupakan jenis yang paling dominan dengan angka mencapai 178 juta pemakai sama dengan 3,8\% dari jumlah penyalahgunaan narkoba. Dari jumlah tersebut, diperkirakan jumlah orang menderita dan ketergantungan akibat mengonsumsi narkoba mencapai 27 juta orang atau $0.6 \%$ populasi usia berkisar $15-64$ tahun. (World Drug Report, 2016)

Indonesia merupakan negara yang berada dalam kondisi gawat narkoba, diperikirakan jumlah penyalahguna narkoba sebanyak 3,8 juta sampai 4,1 juta orang atau sekitar 2,10\% sampai 2,25\% dari total seluruh penduduk Indonesia yang berisiko terpapar narkoba di Tahun 2014. Pada tahun 2017 jumlah penyalahguna Narkoba di Indonesia mencapai 3.376.115 jiwa pada kelompok usia 10-59 tahun. Proporsi jumlah penyalahguna berdasarkan jenis kelamin yaitu $72 \%$ laki-laki setara dengan 2.430 .802 orang dan perempuan sebanyak 28\% setara dengan 945.312 orang. Prevalensi Penyalahgunaan Narkoba di Indonesia Tahun 2017 sebesar 1,77\%. Lebih dari separuh penyalahguna narkoba ditemukan pada kelompok pekerja sebanyak 59\% dengan Proporsi Jumlah penyalahguna setahun terakhir 2017 berdasarkan ketergantungan yaitu pecandu suntik mencapai $1,73 \%$ atau sebanyak 58,498 orang, pecandu bukan suntik 14,49\% atau 489.197 orang, teratur pakai mecapai 27,25\% atau 920.100 orang dan coba pakai yaitu sebanyak 59,53 \% atau 1.908.319 orang. Selain itu, berdasarkan data survei tahun 2017 oleh Badan Narkotika Nasional bahwa proporsi penyalahguna terbesar berdasarkan kelompok yaitu sebanyak 59\% adalah pekerja setara dengan 1.991 .909 orang, 24\% adalah pelajar setara dengan 810.267 orang dan $17 \%$ adalah populasi umum setara dengan 573.939 orang. Jenis narkoba yang paling banyak dikonsumsi oleh penyalahguna narkoba yaitu jenis Ganja, Shabu dan Ekstasi. Tingkat kematian dikalangan penyalahguna narkoba sebanyak 11.071 orang pertahun atau 30 orang meninggal per hari akibat penyalahgunaan narkoba. Estimasi kerugian biaya ekonomi akibat narkoba tahun 2017 yaitu Rp. 77,42 triliun untuk kerugian biaya pribadi (private) pada biaya private sebagian besar digunakan untuk biaya konsumsi narkoba dan sebanyak Rp. 7,27 trilyun untuk kerugian biaya sosial, pada biaya sosial sebagian besar karena akibat kematian terkait narkoba (premature death). (Badan Narkotika Nasional. 2017)

Penyalahgunaan narkotika terjadi diberbagai sudut wilayah Indonesia, salah satunya yaitu di wilayah Provinsi Jawa Barat yang sangat berpotensi untuk menjadi pasar potensial dalam perdagangan dan penyalahgunaan narkoba. Provinsi Jawa Barat dengan luas 35.377.76 km2 menurut Data SIAk Provinsi Jawa Barat didiami penduduk sebanyak 46.497.175 juta jiwa. Penduduk ini tersebar di 26 Kabupatan/Kota, 625 Kecamatan dan 5.899 Desa/Kelurahan (jabarprov.go.id). Melihat jumlah penduduk yang sangat besar tersebut, Provinsi Jawa Barat menjadi wilayah tujuan peredaran Narkotika setelah Jakarta karena memiliki target pemasaran yang sangat bagus. Berdasarkan data yang diperoleh dari BNNP Jawa Barat pada bahwa pada tahun 2013 estimasi jumlah penyalahguna narkoba di Jawa Barat berdasarkan kelompok umur (10-59 tahun) menunjukan tingkat prevalensi pernah memakai narkoba sebesar 5,90\% atau jenis kelamin laki-laki sejumlah 965.932 jiwa dan jenis kelamin perempuan sejumlah 932.299 jiwa daro total jumlah penduduk sebesar 33.173.414 jiwa. Sedangkan prevalensi setahun pakai sebesar 2,2\% atau jenis kelamin laki-laki sebesar 360.178 jiwa dan jenis kelamin perempuan sebesar 347.627 jiwa (P4GN, 2012). Pada tahun 2017 angka prevalensi dan Jumlah Penyalahguna di Jawa Barat menempati urutan pertama dari 34 Provinsi yaitu sebesar 645,482 jiwa atau prevalensi $1.83 \%$ dengan populasi sebanyak 35,242,100 jiwa. Selain itu, Provinsi Jawa barat menduduki urutan pertama dalam Jumlah Kerugian biaya sosial ekonomi akibat penyalahgunaan narkotika pada tahun 2017 yaitu sebanyak Rp 16,192,146 diikuti oleh Jawa Timur menjadi provinsi dengan kerugian biaya sosial ekonomi tertinggi akibat penyalahgunaan narkoba karena jumlah konsentrasi penyalahguna terbanyak di Indonesia terdapat di kedua Provinsi tersebut berdasarkan survei penyalahgunaan narkoba tahun 2017 (BNN, 2017).

Pemerintah terus berupaya mencegah dan memberantas penyalahgunaan narkotika agar jumlahnya tidak terus meningkat. Dengan itu, presiden telah menetapkan Keputusan Presiden Republik Indonesia 
Nomor 23 tahun 2010 tentang badan Narkotika Nasional (BNN) yang sekaligus tidak memberlakukan lagi Keputusan Presiden nomo 116 tahun 1999 tentang Badan Koordinasi Narkotika Nasional (BKNN) dalam menjamin efektivitas pelaksaanaan pengendalian dan pengawasan serta pencegahan dan pemberantasan penyalahgunaan dan peredaran gelap narkotika. Badan Narkotika Nasional adalah sebuah lembaga pemerintahan non kementerian Indonesia yang mempunyai tugas pemerintahan dibidang pencegahan dan pemberantasan penyalahgunaan dan peredaran narkotika. BNNP Jawa Barat dibetuk berdasarkan Peraturan Kepala BNN No: PER/04/V/2010/BNN TentangOrganisasi Tata Kerja (OTK) BNNP dan BNNK.

Upaya serius pemerintah untuk memberantas penyalahgunaan narkotika dapat dilihat dari dikeluarkannya Peraturan Bersama Ketua Mahkamah Agung Republik Indonesia Nomor 1 Tahun 2014 tentang Penanganan Pecandu dan Korban Penyalahgunaan Narkotika ke dalam Lembaga Rehabilitasi. Peraturan ini menerangkan untuk tidak menghukum penjara terhadap pecandu dan korban penyalahguna narkotika dan memberika kriteria secara jelas perbedaan antara penyalahguna dan pengedar narkotika berdasarkan barang bukti yang ditemukan. Selain itu, peraturan tersebut menjelaskan bahwa adanya suatu kewajiban bagi pecandu narkotika untuk melaporkan diri kepada pusat kesehatan masyarakat, rumah sakit, dan/atau lembaga rehabilitasi medis dan rehabilitasi sosial.

Berbagai upaya pemeritah dilakukan untuk mengentaskan permasalahan penyalahgunaan narkotika. Tetapi, dalam kenyataanya kejahatan narkotika belum dapat diatasi dengan maksimal. Masih banyaknya jumlah penyalahgunaan di berbagai daerah membuktikan bahwa pemerintah masih harus menggenjot lebih keras dan mengkaji apa saja yang harus diperbaiki dalam kebijakan untuk mengatasi permasalahan penyalahgunaan narkotika. Maka dari itu, Pemerintah secara rutin harus melakukan evaluasi agar ditemukan apa saja kekurangan dan hal apa saja yang harus diperbaiki dalam upaya melawan kejahatan narkotika.evaluasi merupakan suatu proses dan alat ukur guna mengontrol sejauh mana program penanganan penyalahgunaan berjalan sesuai dengan tujuan dan rencana yang telah ditentukan.

\section{KAJIAN PUSTAKA}

Kebijakan Publik menurut David Easton adalah "the authoritative allocation of value for the whole society-but it turns out that only government can authoritatively act on the 'whole' sociery and everything the government choosed to do or not to results in the 'allocation of value". Jadi kebijakan publik tidak hanya fokus kepada apa yang dilakukan pemerintah, tetapi juga dengan apa yang tidak dilakukan pemerintah. Hal ini seperti yang dikatakan oleh Thomas R. Dye, "public policy is whatever government choose to do or not to do". Sejalan dengan pernyataan tersebut Kebijakan menurut pandangan ilmuan poltik Friederich (dalam Wahab, 2002:13) yang menyatakan bahwa "Kebiajakn ialah suatu tindakan yang mengarah pada tujuan yang diusulkan oleh seseorang, kelompok, atau pemerintah dalam lingkungan tertentu sehubungan dengan adanya hambatan-hambatan tertentu seraya mencari peluangpeluang untuk mencapai tujuan atau mewujudkan sasaran yang diinginkan”. Menurut Riant Nugroho menyebutkan bahwa ada tiga kegiatan pokok yang berkenaan dengan kebijakan publik, yaitu: perumusan kebijakan, implementasi kebijakan, dan evaluasi kebijakan. Tidak hanya Riant Nugroho, beberapa ahli juga telah mengemukakan pendapatnya terkait proses kebijakan publik. James E. Anderson, David W. Brady, dan Charles Bullock III (1978) merumuskan bahwa ada 5 (lima) tahapan dari proses kebijakan publik yaitu policy Agenda, Formulation, Adpotion, Implementation, evaluation. (Nugroho, 2011)

Nugroho (2004:185) menyatakan bahwa evaluasi kebijakan publik tidakhanya berkenaan dengan implementasinya melainkan berkenaan dengan perumusan, implementasi dan lingkungan dari kebijakan publik. Sejalan dengan pernyataan tersebut, Badjuri dan Yuwono (2002:132) menyatakan bahwa Evaluasi kebijakan merupakan salah satu tahapan penting dalam siklus kebijakan.pada umumnya evaluasi kebijakan dilakukan setelah kebijakan publik tersebut diimplementasikan, ini tentunyaya dalam rangka menguji tingkat kegagalan dan keberhasilan, keefektfan dan keefesienan, evaluasi kebijakan setidaknya dimaksudkan untuk memenuhi tiga tujuan utama yaitu:

a. Untuk mengkaji apakah kebijakan yang diimplementasikam telah tercapai tujuannya

b. Untuk menunjukan akuntabilitas pelaksana publik terhadap kebijakan yang telah diimplementasikannya: serta

c. Untuk memberikan masukan padakebijakankebijakan publik yang akan datang.

Rossi dan Freeman, (1982) secara umum tahap implementasi dan evaluasi kebijakan saling berhubungan erat. Kegiatan evaluasi pada dasarnya merupakan satu mata rantai proses kebijakan publik yang menilai konseptualitas dan perancangan implementasi, serta pelaksanaan program intervensi sosial. Evaluasi kebijakan merupakan bagian dari proses kebijakan publik untuk meniai hasil dari kinerja kebijakan. Budiman Rusli (2013:112) menyatakan bahwa dalam praktiknya implementasi kebijakan merupakan suatu proses yang begitu kompleks bahkan tidak jarang bermuatan politis dengan adanya intervensi berbagai kepentingan, sehingga keberadaannya sering dianggap lebih penting dari kegiatan yang lain dalam siklus kebijakan. Dalam konteks ini kesungguhan dan konsistensi dalam implemtasi kebijakan menjadi suatu 


\section{Evaluasi Kebijakan Penanganan Pecandu Narkotika Oleh Badan Narkotika Nasional Provinsi Jawa Barat (Diani Utami Nafisah, Mohammad Benny Alexandri, R. Ira Irawati)}

yang penting karena banyak kebijakan yang sebenarnya telah dikaji dan dirancang dengan cukup baik, dalam pelaksanaanya tidak berhasil karena ketidaksungguhan dan inkonsistensi pelaksana di lapangan. Justru disinilah letak pentingnya sebuah kegiatan yang bernama “evaluasi”, yaitu evaluasi terhadap keseluruhan proses kebijakan yang berguna untuk memastikan pencapaian tujuan.

Syafarudin Alwi.dkk (dalam Winarno, 2012:252-253) mengemukakan faktor-faktor yang berpengaruh terhadap perbaikan kebijakan yaitu: pertama, sejauhmana kebijakan awal dinilai mampu memecahkan persoalan-persoalan publik. Oleh karena itu, evaluasi dilakukan untuk melihat sejauhmana kebijakan yang dijalankan meraih dampak yang diinginkan. Dalam hal ini memperbaiki kondisi sosial yang menjadi sasaran program kebijakan tersebut. Kedua, kemampuan dengan mana kebijakan-kebijakan semacam itu dikelola. Ketiga, kelemahan yang mungkin ada selama proses implementasi kebijakan berlangsung. Keempat, perubahan terhadap kebijakan ditentukan kekuatan politik dan kesadaran dari kelompokkelompok dimana kebijakan tersebut ditujukan.

Langkah-langlah evaluasi yang dikemukakan oleh Harris dikenal dengan The Participatory Model for Evaluation. Model ini berdasarkan Framework for Program Evaluation dari Milstein, waterhall \& Grupu (2000) yang memiliki 6 (enam) langkah evaluasi, yaitu Engage stakeholder (melibatkan para pemangku kepentingan), Describe the program (menjelaskan program), focus the evaluation design (fokus pada desain evaluasi), gather credible evidence (mengumpulkan bukti yang kredibel), justify Conclusion dan Ensure use and sahre lessons learned.

\section{METODOLOGI}

Metode penelitian merupakan proses, prinsip dan prosedur yang digunakan oleh peneliti untuk mendekati probel dan mencari jawaban. Metode penelitian ini merupakan cara ilmiah yang didasarkan para rasionalitas, bersifat empiris dan sistematis yang semuanya memenuhi ciri-ciri keilmuah untuk mendapatkan data dengan tujuan dan kegunaan tertentu. Tujuan dari penelitian ini adalah menganalisis evaluasi kebijakan penanganan pecandu narkotika oleh Badan Narkotika nasional Provinsi Jawa Barat.

Metode yang digunakan oleh penulis adalam metode kualitatif. Moleong menyebutkan bahwa penelitian kualitatif sebagai penelitian yang digunakan untuk meneliti pada kondisi latar objek alamiah, dengan maksud menafsirkan fenomena yang terjadi dan dilakukan dengan jalan melibatkan metode yang ada dan peneliti merupakan instrument kunci. Definisi mengenai penelitian kualitatif yang disampaikan oleh Moleong yaitu "Penelitian kualitatif adalah penelitian yang bermaksud untuk memahami fenomena tentang apa yang dialami oleh subjek penelitian misalnya perilaku, persepsi, motivasi, tindakan, dan lain-lain, secara holistic, dan dengan cara deskripsi dalam bentuk katakata dan bahasa, pada suatu konteks khusus yang alamiah dan dengan memanfaatkan berbagai metode alamiah. "(Moleong, 2007:6)

Pendekatan yang digunakan dalam penelitian ini yaitu studi kepustakaan dan tusi dokumentasi dengan metode penelitian berbasis data sekunder. Menurut Nazir (2009) studi kepustakaan adalah teknik pengumpilan data dengan melakukan penelaahan terhadap berbagai catatan-catatan serta berbagai laporan yang berkaitan dengan masalah yang ingin dipecahkan. Dengan pertimbangan pengumpulan data dalam penelitian ini didasarkan pada penelitian kepustakaan yang meliputi peraturan, dokumen, internet dan sumbersumber tertulis baik tercetak maupun eletronik. Peranan studi kepustakaan dalam penelitian sangatlah penting karena mampu menghubungkan keterkaitan masalah dengan penelitian-penelitian yang relevan dan teori yang akan menjadi lebih jelas.

\section{PEMBAHASAN}

Undang-undang Republik Indonesia Nomor 35 tahun 2009 tentang Narkotika, memberika pengertian mengenai narkotika yaitu zat atau obat yang berasal dari tanaman, baik sintetis maupun semisintetis yang dapat menyebabkan penurunan atau perubahan kesadaran, hilangnya rasa, mengurangi sampai menghilangkan rasa nyeri dan dapat menimbulkan ketergantungan. Selain itu, pengertian pecandu narkotika menurut Undangundang Republik Indonesia Nomor 35 tahun 2009 tentang Narkotika yaitu orang yang menggunakan atau menyalahgunakan narkotika dan dalam keadaan ketergantungan pada narkotika baik secara fisik maupun psikis. Peran serta pemerintah daerah dalam hal ini BNNP, BNN Kabupaten, dan BNN Kota adalah lembaga teknis daerah berbentuk badan yang melaksanakan P4GN sesuai dengan Keputusan ketua BNN Nomor: KEP/07/XI/2002/BNN (Nasution, dkk.,2006).Tugas dan fungsi dari pada BNN Provinsi, Kabupaten, dan Kota antara lain (Nasution, dkk, 2006):

a. Melakukan Pembinaan, pengawasan, dan pengendalian terhadap seluruh kegiatan yang berhubungan dengan narkotika yang dilakukan oleh instansi pemerintah dan organisasi nonpemerintah.

b. Mengkoordinasikan instansi pemerintah terkait di daerahnya dalam penyusunan kebijakan teknis dan pelaksanaannya di bidang ketersediaan, pencegahan dan pemberantasan penyalah- gunaan dan peredaran gelap narkotika, psikotropika, prekursor, dan zat adiktif lainnya;

c. Melaksanakan pencegahan, dan pemberantasan penyalahgunaan dan peredaran gelap narkotika, psikotropika, prekursor dan zat adiktif lainnya dengan membentuk satuan 
tugas-satuan tugas yang terdiri dari instansi pemerintah terkait di daerahnya sesuai dengan tugas, fungsi dan kewenangannya masingmasing.

Terdapat tiga jaringan penyebaran dan modus operandi ke wilayah Jawa Barat:

1. Jaringan ganja. Berasal dari Aceh, Bengkulu dan Palembang dipasol lewat Jakarta. Setelah itu didistribusikan ke wilayah Jawa Barat melalui Bogor diteruskan ke tiga wilayah yaitu Bandung, Cikampek dan Cirebon. Dari Bandung menyebar ke wilayah Sukabumi, selanjutnya ke wilayah Tasikmalaya dan Ciamis. Dari Cikampek ke wilayah Purwakarta dan subang dan dari cirebon ke wilayah Indramayu dan Kuningan.

2. Jaringan psikotropika, Shabu dan Ekstasi. Zat tersebut berasal dari luar negeri dari Bangkok dan Manila. Jalur masuk ke Indonesia melalui singapura menuju Batam. Di Indonesia, ditribusikan melalui Batam menuju ke Medan maupun Jakarta, setelah itu baru didistribusikan ke seluruh wilayah Indonesia salah satunya wilayah Jawa Barat terpusat ditiga wilayah yaitu Bandung, Bogor, Cirebon. Dari wilayah tersebut sampai ke daerahdaerah, sampai ke daerah Cimahi, Tasikmalaya, dan Purwakarta. Dari Cihami ke Sumedang; dari Tasikmalaya diteruskan ke Ciamis, Garut, banjar dan Purwakarta diteruskan ke wilayah Subang.

3. Jaringan Narkotika Heroin, diimport dari luar negeri melalui perantara Warga Negara Asin (WNA) kulit hitam. Barang tersebut masuk di Indonesia melalui Jakarta melalui jalur udara. Peredaran heroin di wilayah Jawa Barat, dipasok dari Jakarta ke Wilayah Bandung. Melalui Bandung baru didistribusikan ke kotakota besar di wilayah Jawa Barat, antara lain Cianjur, Bogor, Garut, Tasikmalaya dan Cirebon.

Penanganan pecandu narkotika di wilayah Jawa Barat sepertinya belum dilakukan dengan maksimal. Hal ini dapat dilihat dari jumlah penyalahgunaan narkotika yang masih sangat tinggi. Perlu dilakukan Evaluasi dengan baik dan benar agar dapat memperbaiki hal-hal apa saja yang wajib dibenahi. Pembahasan yang akan diuraikan penulis yaitu mengapa evaluasi penanganan pecandu narkotika oleh Badan Narkotika Nasional Provinsi Jawa Barat belum dilakukan dengan maksimal. Dalam penelitian ini penulis menggunakan enam dimensi langkah-langkah evaluasi yang dikemukakan oleh Milstein untuk mengevaluasi penanganan pecandu narkotika oleh Badan Narkotika Nasional Provinsi Jawa Barat. Langkah-langkah evaluasi tersebut yaitu Engage stakeholder, Describe the program, focus the evaluation design, gather credible evidence, justify conlusions, ensure use and share lessons learned.

\section{a. Engage Stakeholder}

Melibatkan stakeholder utama dalam pelaksanaan evaluasi yaitu kelompok yang terlibat dalam penanganan penyalahgunaan narkotika. Dalam melaksanakan evaluasi, Badan Narkotika Nasional Provinsi Jawa Barat harus melibatkan seluruh stakeholder karena hal tersebut adalah satu bagian yang penting agar tujuan evaluasi tercapai. Stakeholder dapat memberikan informasi yang berguna terkait penanganan yang dilakukan.

\section{b. Describe the Program}

Sebelum stakeholder dapat berbicara tentang evaluasi, mereka harus mengetahui program ini secara menyeluruh agar dapat menetapkan kerangka acuan untuk semua keputusan dalam evaluasi.dalam sebuah proses evaluasi progtam dibutuhkan sejauh mana pengetahuan evaluator mengenai program tersebut. Pemahaman yang kuat tentang penanganan merupakan langkah yang penting dalam pelaksanaan evaluasi agart tidak ada kekeliruan ketika evaluasi dilakukan. Stakeholder harus memahami detail mengenai visi, misi, tujuan dan strategi penanganannya.

\section{c. Focus the Evaluations Design}

Melakukan perencanaan terlebih dahulu tentang dimana evaluasi dipimpin dan langkahlangah apa yang akan diambil. Hal ini berkenaan dengan penetapan perencananaan evaluasi yaitu menguraikan strategi mengenai cara mendapatkan dan menganalisis data yang akan membantu meningkatkan efektivitas dari suatu evaluasi. Perencanaan evaluasi harus dirancang sebelum evaluasi dilakukan karema hatis ada fokus dalam penanganan. Sangat dibutuhkan perencanaan evaluasi yang matang dan menyeluruh guna menciptakan strategi evaluasi yang sangat efektif dengan menetapkan standar operasional prosedur dalam evaluasi.

\section{d. Gather Credible Evidence}

Mengumpulkan informasi yang kredibel karena akan membantu hasil evaluasi yang baik. Hal ini berkenaan dengan pengumpulan bukti-bukti terkait penanganan pecandu narkotika. Informasi yang kredibel merupakan bahan baku dari evaluasi yang baik. Dalam mengumpulkan informasi yang kredibel dibutuhkan aspek-aspek seperti indikator, sumber-sumber, kualitas dan kuantitas.yang dimaksud dengan indikator dalam hal ini yaitu jenis informasi seperti apa saja yang 
dibutuhkan. Sumber-seumber yaitu siapa saja yang menjadi sumber informasi dalam evaluasi. Kualiats berhubungan dengan sejauh mana informasi yang dikumpulkan dapat berguna dalam evaluasi. Kuantitas berhubungan dengan seberapa banyak informasi yang dibutuhkan dalam pelaksanaan evaluasi.

\section{e. Justify conclusions}

Pembenaran kesimpulan dengan bukti yang dikumpulkan dan konsisten dengan nilai atau standar yang telah ditetapkan. Hal ini berkaitan dengan pembenaran-pembenaran informasi yang telah didapatkan. Dalam pelaksanaan evaluasi dibutuhkan bukti dan data yang kongkrit. Data yang didapat harus dipertimbangkan dengan hati-hati dari sejumlah perspektif pemangku kepentingan yang berbeda-beda agar dapar menciptakan kesimpulan yang dapat dipertanggung jawabkan kebenarannya. Pembenaran kesimpulan dapat disetujui apabila sesuai dengan bukti yang dikumpulkan dan konsisten dengan nilai-nilai dan standar yang telah ditetapkan.

\section{f. Ensure use and share lessons learned}

Menyebabkan hasil evaluasi kepada seluruh stakeholder yang terlibat sehingga dapat menjadi pembelajaran guna langkah yag lebih baik. Hal ini bekaitan dengan memastikan penggunaan evaluasi apakah sudah dilakukan dengan jelas dan apakah hasil evaluasi tersebut sudah disebarkan kepada pihak terkait guna berbagi pelajaran untuk eksistensi program pembinaan selanjutnya.

\section{KESIMPULAN}

Badan Narkotika Nasional adalah sebuah lembaga pemerintahan non kementerian Indonesia yang mempunyai tugas pemerintahan dibidang pencegahan dan pemberantasan narkotika. Badan Narkotika Nasional dipimpin oleh seorang kepala yang bertanggung jawab kepada presiden melalui Kepala Kepolisian Republik Indonesia. Dasar hukum Badan Narkotika Nasional sebagai lembaga pemerintahan non kementerian adalah Peraturan Presiden Nomer 23 Tahun 2010 tentang badan Narkotika Nasional. Badan Narkotika Nasional Provinsi Jawa Barat dibentuk berdasarkan Peraturan Kepala BNN No: PER/04/V/2010/BNN Tentang Organisasi Tata Kerja (OTK) BNNP dan BNNK.

Jumlah penyalahgunaan narkotika di Provinsi Jawa Barat berada dalam angka yang sangat tinggi. Ironisnya, pada tahun 2017 angka Prevalensi dan Jumlah Penyalahguna di Jawa Barat menempati urutan pertama dari 34 Provinsi yaitu sebesar 645,482 jiwa atau prevalensi 1.83\% dengan populasi sebanyak 35,242,100 jiwa. Selain itu, Provinsi Jawa barat menduduki urutan pertama dari 34 provinsi dengan Jumlah Kerugian biaya sosial ekonomi akibat penyalahgunaan narkotika pada tahun 2017 yaitu sebanyak Rp 16,192,146. Permasalahan ini bukan lagi hal yang bisa dianggap sepele karena masalah ini memberikan dampak yang sangat besar. Bahkan, permasalahan penyalahgunaan narkotika sudah dianggap sebagai bencana global.

\section{DAFTAR PUSTAKA}

Moleong, Lexy J. 2007. Metodologi Penelitian Kualitatif. Bandung: PT. Remaja Rosdakarya.

Nugroho, Riant. 2003. Kebijakan Publik, Formulasi, implementasi, evaluasi. Jakarta: Elex Media Komputindo.

Nugroho, Riant D. 2011. Public Policy Dinamika Kebijakan, Analisis Kebijakan, Manajemen Kebijakan. Jakarta: PT. Elex Media Komputindo

Undang-undang No. 35 Tahun 2009 tentang Narkotika Instruksi Presiden Republik Indonesia Nomor 12 Tahun 2011 Tentang Pelaksanaan Kebijakan dan Strategi Nasional Pencegahan dan Pemberantasan Penyalahgunaan dan Peredaran Gelap Narkoba.

Peraturan Bersama Ketua Mahkamah Agung Republik Indonesia Nomor 1 Tahun 2014 tentang Penanganan Pecandu dan Korban Penyalahgunaan Narkotika ke dalam Lembaga Rehabilitasi

Peraturan Presiden Nomer 23 Tahun 2010 tentang badan Narkotika Nasional

Survei Nasional Penyalahgunaan Narkoba di 34 Provinsi Tahun 2017 oleh Badan Narkotika Nasional

Evaluasi Kerjasam UNDOC dan Pemerintah Indonesia dalam Mengatasi perdagangan Narkoba Jenis Crystaline Methamphetamine di Indonesia (20072013)

HEALTH PROMOTION PRACTICE Article: A Framework Featuring Steps and Standards for Program Evaluation A scientist in drug policy in Washington, DC Narcotics and Drug Abuse Public Policy Proposals for Regulating Drugs and Reducing Risk and Harm: Options and Strategies 